\title{
Biochemical compounds and sub-chronic toxicity test of Chlorella sp. and Spirulina sp. isolated from Glagah Coastal Water
}

\author{
Slamet Widiyanto*, Mulyati Sarto, Laksmindra Fitria, Rahadian Yudo, Eko Agus Suyono. \\ Laboratory of Animal Physiology and Biotechnology, Department of Tropical Biology, Faculty of Biology, Universitas Gadjah Mada, Yogyakarta, \\ Indonesia.
}

\begin{abstract}
Microalgae are microscopic photosynthetic organisms found in marine and freshwater environments. This organism is a eukaryotic group of polyphyletic and very diverse. This study investigated the biochemical composition and sub-chronic test of Chlorella Sp. and Spirulina Sp. isolated from Glagah coastal water (Yogyakarta, Indonesia) as a preclinical study to create potential nutritional supplement for human health. Microalgae culture was analyzed for biochemical composition using several methods: AAS for metal analysis ( $\mathrm{Pb}, \mathrm{Cu}, \mathrm{Fe}, \mathrm{Mg}, \mathrm{Zn}$, and $\mathrm{Hg}$ ), GC-MS and UV spectrophotometer for fatty acid profiles analysis (lenolenic acid, eicosatrienoic acid, arachidonic acid, linoleic acid, oleic acid, eicosenoic acid, EPA, DHA, omega 6 and 9), Alkaloids, Steroids, Tanin and Saponin. The next step is to do a sub-chronic test of microalgae biomass using experimental animals. The result shows that Spirulina sp. and Chlorella sp. contain 16 and 10 different biochemical compounds respectively. Furthermore, organic nutritional properties in both of microalgae are relatively high with a rich biochemical profile of Fe and nutritious poly-unsaturated fats (such as linolenic acid, arachidonic acid, omega 6, and 9). Regarding sub-chronic toxicity test, it was clear that Spirulina and Chlorella did not affect the blood profile. These findings suggest that both of Glagah strain microalgae are considered to have great potential as a multi-nutritional human health supplement.
\end{abstract}

Keywords: Biochemical composition, blood profile, Chlorella Sp., Glagah Coastal, Spirulina Sp.

Received: 25 October 2018 Revised: 21 December 2018 Accepted: 28 December 2018

\section{Introduction}

Currently, there has been commercialization of Spirulina and Chlorella as functional food to improve human and animal health (Hutadilok-Towatana et al., 2010). Spirulina sp. and Chlorella sp., are microscopic, unicellular, and photosynthetic aquatic algae. It has been used for hundreds of years as a food source for humans and animals. Due to excellent nutritional profile, as a rich source of nutrients and biologically active substances, such as protein, amino acids, polyunsaturated fatty acids, microelements, vitamins, antioxidants, and carotenoids.

Spirulina belongs to the cyanobacterium group with the characteristic multicellular trichomes in the cylindrical shape. These microalgae have high protein content and are rich in vitamins, minerals, and other components that are beneficial to health such as essential fatty acids and antioxidant pigments such as carotenoids, chlorophyll, and fikocyanin (Hutadilok-Towatana et al., 2010). In addition, another microalgae that has a high protein content is Chlorella. This algae in addition to providing the majority of amino acids, also contains many vitamins and minerals. Chlorella also contains Chlorella Growth Factor that can strengthen immunity and prevent or destroy cancer wounds (Tang and Suter, 2011), while Spirulina is widely used as a supplement to animal feed. Based on previous research, the addition of $10 \%$ or $20 \%$ Spirulina decreased the rate of chicken growth. Addition of 50-100

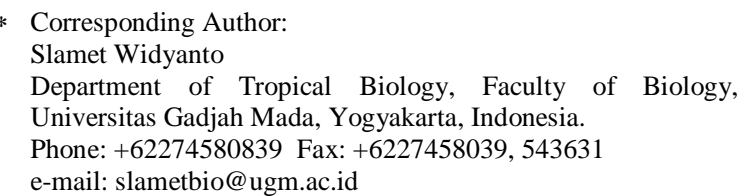

$\mathrm{g} / \mathrm{kg}$ of Spirulina in feed ratio will keep the growth rate while the excess level of $200 \mathrm{~g} / \mathrm{kg}$ will decrease the growth rate of chicken (Holman and Malau-Aduli, 2013). Another research resulted the addition of Spirulina on the best poultry diet ranged from $0.5 \%-12.5 \%$. Based on the research of Cheong et al. (2015) recommended addition of $4 \%$ Spirulina on quail feed resulted in good performance, weight of karakas, and meat quality.

Thus, it is necessary to conduct research to determine biochemical compounds of Spirulina and Chlorella before it was tested by sub-chronic toxicity of to test animals especially to know its effect on hematology profile. The final purpose of this research is to create nutraseutical products microalgae to create potential nutritional supplement for human health. Before, in the first phase, nutrient content of microalgae has been obtained by HPLC (High Performance Liquid Chromatography), AAS (Atomic Absorption Spectroscopy) and GC-MS (Gas Chromatography-Mass Spectrometry) methods. Furthermore, nutraseutical formulation has been obtained preclinically concerning the sub-chronic toxicity of Spirulina and Chlorella microalgae through animal model in particular to determine its effect on the hematologic profile.

\section{Method}

\section{Ethical Clearance}

This research method has been approved by ethical commission for preclinical research in The Integrated Research and Testing Laboratory Universitas Gadjah Mada through The Certificate of Ethical Clearance No: 00044/04/LPPT/VIII/2016, date 01 August 2016. 


\section{Preparation of Microalgae}

Microalgae was cultured at Biotechnology Laboratory, Faculty of Biology, Universitas Gadjah Mada, Indonesia.

\section{Analysis Microalgae Nutrient Content}

Microalgae are cultivated using a medium F/2 + silica in liquid form which is taken $1 \mathrm{ml}$ of liquid silica solution with a concentration of $30 \mathrm{mg} / \mathrm{L}$. The dry weight of samples is taken on days $0,7,14$ and 21 as much as $2 \mathrm{~mL}$ for a scale laboratory. After 21 days the microalgae was harvested and used to be tested on experimental animals and nutrian analysis and chemical profile. Microalgae biochemical and heavy metal profile were analyzed by AAS; GC-MS and spectrophotometer for fatty acid and other compounds. Biochemical profile was analysis by GC-MS at Chemistry Department Laboratory, Faculty of Mathematics and Natural Sciences, Universitas Gadjah Mada. A hundred gram of microalgae were dried in temperature $45^{\circ} \mathrm{C}$ until the weight is constant, $64.45 \mathrm{~g}$ of peeled single black garlic was crushed with blender and followed by maceration using ethanol $70 \%$ for $24 \mathrm{~h}$, repeated three times. The filtrate was collected and was evaporated in $45{ }^{\circ} \mathrm{C}$, the crude ethanol extract was collected. For the $\mathrm{n}$-hexane fraction, $10 \mathrm{~g}$ of ethanol extract was dissolved in $100 \mathrm{~mL}$ ethanol and partitioned with $100 \mathrm{~mL}$-hexane. The upper suspension layer was filtered and evaporated at $45^{\circ} \mathrm{C}$, the ethanol extract and nhexane fraction were kept at $4{ }^{\circ} \mathrm{C}$ before use. The ethanol extract and $\mathrm{n}$-hexane fraction from microalgae were analyzed using GCMS-QP2010S (Shimadzu Co., Japan) instrument with AGILENT HP 5MS capillary column of $0.25 \mu \mathrm{m}$ thickness, $0.25 \mathrm{~mm}$ diameter insert and $30 \mathrm{~m}$ long. The analysis was performed by injecting $1 \mu \mathrm{L}$ sample (ethanol extract and n-hexane fraction of microalgae). Helium gas ( $\mathrm{He}$ ) is used as a carrier gas with a flow rate of $3 \mathrm{~mL} / \mathrm{min}$. The ionization electron system with $70 \mathrm{eV}$ ionization energy is used for GC-MS detection. The initial $50{ }^{\circ} \mathrm{C}$ column temperature held for 5 min was then gradually increased to $280{ }^{\circ} \mathrm{C}$ with an increase of $5{ }^{\circ} \mathrm{C}$ per minute. Then when the temperature reached $280{ }^{\circ} \mathrm{C}$ held for $19 \mathrm{~min}$. The obtained spectra were then compared to the database in WILEY libraries (Hoboken, 2012).

\section{Animal and Experimental Design}

Fifteen male Wistar rats were purchased from The Integrated Research and Testing Laboratory Universitas Gadjah Mada. The animals were divided into three groups consisting of five animals per group. Group I were placebo control, group II and III are Treatment Groups, were treated with dry biomass of Spirulina 5000 $\mathrm{mg} / \mathrm{kgWB}$ and Chlorella $5000 \mathrm{mg} / \mathrm{kgWB}$ orally, respectively.

\section{Sub-Chronic Toxicity Test}

Sub-chronic Toxicity Test conducted by giving microalgae orally every morning and evening for 90 days. The physiological conditions of the test animals were observed in the day of $0,30,60$ and 90 by studying the hematology profiles such as red blood cells, white blood cells, and platelets (PLT). Red blood cells include the total number of red blood cells (RBC), hemoglobin (HGB), and hematocrit (HCT), Mean Corpuscular Volume (MCV), Mean Corpuscular Hemoglobin (MCH), and Mean Corpuscular Hemoglobin Concentration (MCHC). White blood cells include the total number of white blood cells (WBC), the percentage of lymphocytes (LYM) and the percentage of neutrophils (NEUT). Platelets include the total number of PLT, platelecrit (PCT), and Platelet Distribution Width (PDW). At the end of the study, the rats were anesthetized using ketamine for blood collection. Then, the mice were mutated by eksanguinasi (Muñoz-Antoli et al., 2015) .

\section{Data Analysis}

The haematological data were tabulated and analyzed statistically using Two-Way ANOVA with 95\% confidence level. If there is any difference, then proceed with Post hoc LSD. If the data obtained are not homogeneous, then it is analyzed by using One-Way ANOVA by using software program (software) SPSS 20.

\section{Results}

\section{Nutritional and Chemical Profile of Spirulina sp.}

Analysis on the content of volatile compounds on Spirulina sp. and Chlorella sp. were done using GC-MS method. Based on figure 1, the chromatogram of Spirulina sp. was obtained 26 peak and successfully identify 19 compounds while Chlorella sp was obtained 11 peak and successfully identify 10 compounds. Tabel 1 shown the biochemical profile of Spirulina sp. The volatile compounds of Spirulina sp. were successfully identified various classes of biochemical compounds including cycloalkanes, benzenes, alkanes, terpenes, monoterpenes, alcohol, fatty acids, carotenoids, benzene and fatty alcohol groups, whereas in the fraction of nHexane have been identified 26 compounds, originating from various groups between other classes of alkanes, fatty acids and organochloride. Chlorella's compounds came from various classes of compounds including phenyl propanoids, terpenes, sesquiterpenes, fatty acids and alkanes.

The results of GC-MS analysis as shown in table 1, indicate the abundance of biomolecules as shown by their peaks, including cyclooctanone, toluene, ethylbenzene, alpha-pinene, eucalyptol, tridecane, tetradecane, eicosane, hexadecane, octadecane, octadecanoid acid, heneicosane, methyl 9,9-dideutero-octadecanoate and 2h-1,4benzodiazepin-2-one, 7 chloro-1,3-dihydro-5-phenyl-.

\section{Nutritional and Chemical Profile of Chlorella sp.}

The biochemical compounds of Chlorella sp. were eugenol, azulene, hexadecanoid acid, methyl 9,9dideutero-octadecanoate, 1,2-benzenedicarboxylic acid, santalol, tridecane, hexatriacontane and dodecanoic acid as shown in table 2. Eugenol can be used in perfumes, flavorings, and essential oils. It is also used as a local antiseptic and anaesthetic. The dominant compound that is found in Chlorella is fatty acid such as hexadecanoic acid, methyl 9,9-dideutero-octadecanoate, 1,2benzenedicarboxylic acid and dodecanoic acid. 


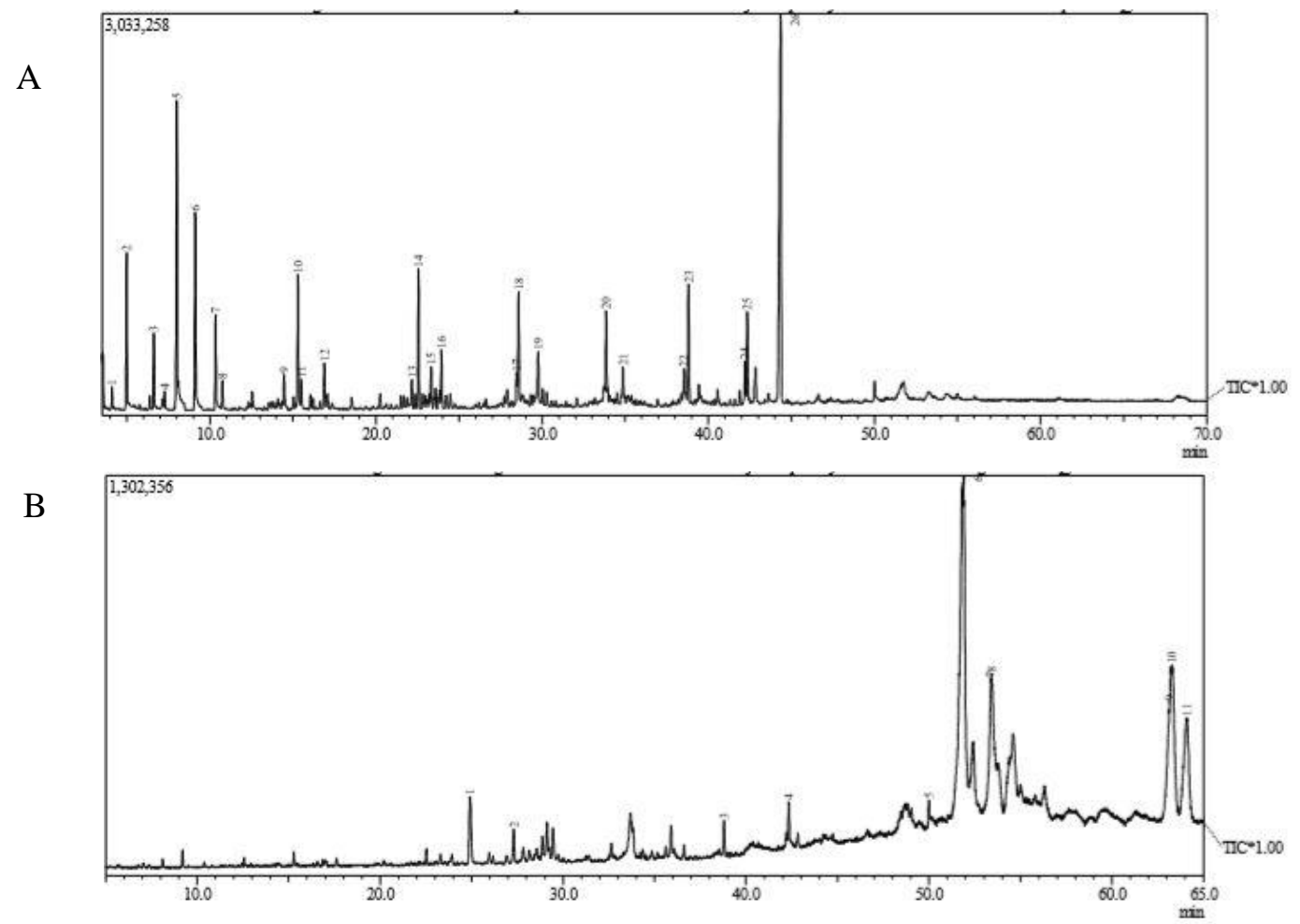

Figure 1. Chromatogram of Spirulina sp. (a) and Chlorella sp. (b)

Table 1. Chemical compounds of Spirulina Sp.

\begin{tabular}{|c|c|c|c|}
\hline No & Structure & Name & Class \\
\hline 1 & $\mathrm{C}_{8} \mathrm{H}_{14} \mathrm{O}$ & Cyclooctanone (CAS) & Cycloalkane \\
\hline 2 & $\mathrm{C}_{7} \mathrm{H}_{8}$ & Toluene & Benzene \\
\hline 3 & $\mathrm{C}_{9} \mathrm{H}_{20}$ & Hexane,2,3,4-Trimethyl- & Alkane \\
\hline 4 & $\mathrm{C}_{9} \mathrm{H}_{18}$ & 2,4-Dimethyl-L-Heptene & Alkene \\
\hline 5 & $\mathrm{C}_{8} \mathrm{H}_{10}$ & Ethylbenzene & Benzene \\
\hline 6 & $\mathrm{C}_{8} \mathrm{H}_{8}$ & $\begin{array}{l}\text { Bicyclo[4,2,0]octa-1,3,5- } \\
\text { Triene(CAS)BYCYCLO(4,2,0)OCTA- } \\
\text { 1,3,5-TRIENE, Benzenocyclobutane } \\
\text { Benzenocyclobutane, 1,2-dihydro- } \\
\text { Cardene,1,2Dihidrobenzocyclobutene }\end{array}$ & Benzene \\
\hline 7 & $\mathrm{C}_{9} \mathrm{H}_{12}$ & Benzene,(1-methylethyl)- & Benzene \\
\hline 8 & $\mathrm{C}_{10} \mathrm{H}_{16}$ & Alpha,-Pinene & Terpene \\
\hline 9 & $\mathrm{C}_{10} \mathrm{H}_{8} \mathrm{O}$ & Eucalyptol & Monoterpenes \\
\hline 10 & $\mathrm{C}_{13} \mathrm{H}_{28}$ & Tridecane & Alkane \\
\hline 11 & $\mathrm{C}_{13} \mathrm{H}_{28}$ & Tridecane & Alkane \\
\hline 12 & $\mathrm{C}_{13} \mathrm{H}_{28}$ & Tridecane (CAS) n-tridecane & Alkane \\
\hline 13 & $\mathrm{Cl}_{4} \mathrm{H}_{30}$ & $\begin{array}{l}\text { Tetradecane }(\mathrm{CAS}) \mathrm{n} \text {-Tetradecane } \\
\text { Isotetradecane }\end{array}$ & Alkane \\
\hline 14 & $\mathrm{C}_{20} \mathrm{H}_{42}$ & Eicosane n-Eicosane & Alkane \\
\hline 15 & $\mathrm{C}_{12} \mathrm{H}_{26} \mathrm{O}$ & 1-octanol, 2-butyl- & Alcohol \\
\hline 16 & $\mathrm{C}_{16} \mathrm{H}_{34}$ & Hexadecane & Alkane \\
\hline 17 & $\mathrm{C}_{20} \mathrm{H}_{42}$ & Eicosane n-Eicosane & Alkane \\
\hline 18 & $\mathrm{C}_{18} \mathrm{H}_{38}$ & Octadecane & Alkane \\
\hline 19 & $\mathrm{C}_{20} \mathrm{H}_{42}$ & Eicosane n-Eicosane & Alkane \\
\hline 20 & $\mathrm{C}_{18} \mathrm{H}_{38}$ & Octadecane & Alkane \\
\hline 21 & $\mathrm{C}_{18} \mathrm{H}_{38}$ & Octadecane & Alkane \\
\hline 22 & $\mathrm{C}_{21} \mathrm{H}_{44}$ & Heneicosane n-Heneicosane & Alkane \\
\hline 23 & $\mathrm{C}_{19} \mathrm{H}_{38} \mathrm{O}_{2}$ & Octadecanoid acid, methyl ester & Fatty acid \\
\hline 24 & $\mathrm{C}_{19} \mathrm{H}_{34} \mathrm{O}$ & 8,11-octadecanoid acid, methyl ester & Fatty acid \\
\hline 25 & $\mathrm{C}_{19} \mathrm{H}_{36} \mathrm{D}_{2} \mathrm{O}_{2}$ & Methyl 9,9-Dideutero-Octadecanoate & Fatty acid \\
\hline 26 & $\mathrm{C}_{15} \mathrm{H}_{11} \mathrm{ClN}_{2} \mathrm{O}$ & $\begin{array}{l}\text { 2H-1,4-Benzodiazepin-2-one, } 7 \\
\text { chloro-1,3-dihydro-5-phenyl- }\end{array}$ & Organochloride \\
\hline
\end{tabular}


Table 2. Chemical compounds of Chlorella Sp.

\begin{tabular}{|c|c|c|c|}
\hline No & Structure & Name & Class \\
\hline 1 & $\mathrm{C} 12 \mathrm{H} 12 \mathrm{O} 2$ & Eugenol & Phenylpropanoid \\
\hline 2 & & Azulene, $1,2,3,4,5,6,7,8$ & \\
\hline & $\mathrm{C} 15 \mathrm{H} 24$ & $\begin{array}{l}\text { octahydro-1,4-dimethyl-7-(1- } \\
\text { methylethenyl)-, 1S-(1alpha., } \\
\text { 4.alpha., 7.alpha.)- }\end{array}$ & Terpene \\
\hline 3 & $\mathrm{C} 17 \mathrm{H} 34 \mathrm{O} 2$ & $\begin{array}{l}\text { Hexadecanoic acid, methyl } \\
\text { ester }\end{array}$ & Fatty acid \\
\hline 4 & $\mathrm{C} 19 \mathrm{H} 36 \mathrm{D} 2 \mathrm{O} 2$ & $\begin{array}{l}\text { Methyl 9,9-dideutero- } \\
\text { octadecanoate }\end{array}$ & Fatty acid \\
\hline 5 & $\mathrm{C} 24 \mathrm{H} 38 \mathrm{O} 2$ & $\begin{array}{l}\text { 1,2-Benzenedicarboxylic acid, } \\
\text { diisooctyl ester }\end{array}$ & Fatty acid \\
\hline 6 & $\mathrm{C} 15 \mathrm{H} 24 \mathrm{O}$ & $\begin{array}{l}\text { Alpha,-Santalol 2-Penten-1-ol, } \\
\text { 5,-(2.3dimetyltricylol } \\
\text { [2.2.1.0(2.6)hept-3-yl)-2- } \\
\text { methyl-, stereoisomer (CAS) 2- } \\
\text { Penten-1-ol, 5,- } \\
\text { (2.3dimetyltricylol } \\
\text { [2.2.1.0(2.6)hept-3-yl)-2- } \\
\text { methyl-,[R-(Z)]-(CAS)S }\end{array}$ & Sesquiterpene \\
\hline 7 & $\mathrm{C} 15 \mathrm{H} 24 \mathrm{O}$ & Santalol & Sesquiterpene \\
\hline 8 & $\mathrm{C} 15 \mathrm{H} 24 \mathrm{O}$ & Santalol & Sesquiterpene \\
\hline 9 & C19H40 & $\begin{array}{l}\text { Tridecane, 7-hexyl-7- } \\
\text { Hexyltridecane }\end{array}$ & Alkane \\
\hline 10 & $\mathrm{C} 36 \mathrm{H} 74$ & Hexatriacontane & Alkane \\
\hline 11 & C39H74O6 & $\begin{array}{l}\text { Dodecanoic acid, 1,2,3- } \\
\text { propanetryl ester (CAS), } \\
\text { Glyceril tridodecanoate, } \\
\text { Trilaurin, Laurin, tri-Glycerol } \\
\text { trilaurate, Glyceril trilaurate, } \\
\text { lauric acid triglyceride, Lauric } \\
\text { acid triglycerin ester }\end{array}$ & Fatty acid \\
\hline
\end{tabular}

\section{Discussion}

Octadecanoic acid is anti-inflammatory, hypocholesterolemic, cancer preventive, hepatoprotective, nematicide, insectifuge, antihistaminic, antieczemic, antiacne, 5-alpha reductase inhibitor, antiandrogenic, antiarthritic, anticoronary, antipsychotic and insectifuge (Dandekar et al., 2015). Eicosane derivative is a good antioxidant (Linton et al., 2013). Alkanes compounds are the major volatile compounds in Spirulina sp which generally have anti-inflammatory, antiarthritic, antidiabetic, antiulcer, hypolipidemic, antiatherosclerotic, anti-HIV and cytotoxic activities (Safayhi and Sailer, 1997).

In addition, Eucalyptol contained in Spirulina is the main compound of essential oils of many plant. As an isolated compound, eucalyptol is known for its mucolytic and spasmolytic action in the respiratory tract, with proven clinical properties. It has also shown therapeutic benefits in inflammatory airway diseases, such as asthma and chronic obstructive pulmonary disease (Juergens, 2014). At low exposure levels, Alpha-Pinene generally is a bronchodilator in humans, and is highly bioavailable with $60 \%$ human pulmonary uptake with rapid metabolism or redistribution. Alpha-Pinene is an antiinflammatory via PGE1 (Russo, 2011), and seems to be an antimicrobial (Nissen et al., 2010). It exhibits activity as an acetylcholinesterase inhibitor, aiding memory and acts as a positive modulator of GABAA receptors at the benzodiazepine binding site (Yang et al., 2016).

Hexadecanoic acid is antioxidant, hypocholesterolemic, nematicide, pesticide, and lubricant, antiandrogenic, as flavoring agents, hemolytic and as 5- alpha reductase inhibitor. (Rajeswari et al., 2013). Based on reseach that has been done, dodecanoid acid or lauric acid (LA) has been associated to certain health-promoting benefits of coconut oil intake, including the improvement of the quality of life in breast cancer patients during chemotherapy. As it concerns the potential to hamper tumor growth, LA was shown to elicit inhibitory effects only in colon cancer cells (Lappano et al., 2017).

Eugenol also can be combined with zinc oxide to form zinc oxide eugenol which has restorative and prosthodontic applications in dentistry. For example, zinc oxide eugenol is used for root canal sealing. Moreover, it detected a substance of azulene. It functions as a skin conditioning agent in cosmetic formulations, including hair dyes. Azulene is reported to be used in a wide range of cosmetic formulations, but these reported uses are likely to be uses of guaiazulene, a chemically related colorant, because there are currently no suppliers of Azulene to the cosmetics industry. The anti-inflammatory action of Azulene has been demonstrated in several animal studies. Effects at the cellular level are reported to include inhibition of respiration and growth, but no effect on ciliary activity or membrane permeability (Andersen, 1999). Chlorella also contains santalol that generally used as anticancer. A reseach by Bommaredy et al. (2012) showed that santalol able to against the development of skin cancer and human prostate cancer both in vitro and in vivo. Santalol induced apoptotic cell death and activation of caspase- 3 .

From the table 3, it is clear that both of Chlorella and Spirulina contain five different heavy metals such as $\mathrm{Cu}$, 
$\mathrm{Cd}, \mathrm{Fe}, \mathrm{Mg}$ and $\mathrm{Zn}$. The levels of all types of metals measured in chlorella are higher than Spirulina, except $\mathrm{Cd}$ and Fe. The large gap is detected in Fe where Spirulina consist almost double than Chlorella. The high number of Fe reveals that both of that microalgae have potency as therapy agent of anemia. Similarly, $\mathrm{Zn}$ is one of the most important trace elements in the organism, with three major biological roles, as catalyst, structural, and regulatory ion (Chasapis et al., 2012).

Spirulina and Chlorella also contain omega 3, omega 6 and omega 9 that is play an important roles in the body system. The result shows that Spirulina contains methals and biochemical profile, while Chlorella with the exception of EPA and DHA. A high number of omega 3, 6 and 9 depicts that Spirulina has a potency to be a multinutritional human health supplement. The steroid consisting in Spirulina and Chlorella is a potential compound to make as supplement because it is a basic to form hormones and it can impact a number of things from growth to sexual development (Fountain et al., 2008).

Table 3. Biochemical Profile of Chlorella sp. And Spirulina sp.

\begin{tabular}{|c|c|c|c|c|}
\hline No & Test Parameters & Unit & Chlorella sp. & Spirulina sp. \\
\hline 1 & $\mathrm{Cu}$ (Copper) & $\mathrm{mg} / \mathrm{kg}$ & $<0.01$ & $<0.01$ \\
\hline 2 & $\mathrm{Cd}$ (Cadmium) & $\mathrm{mg} / \mathrm{kg}$ & $<0.01$ & $<0.01$ \\
\hline 3 & $\mathrm{Fe}$ & $\mathrm{mg} / \mathrm{kg}$ & 741.51 & 1323.9 \\
\hline 4 & Mg (Magnesium) & $\% \mathrm{~b} / \mathrm{b}$ & 1.75 & 0.73 \\
\hline 5 & $\mathrm{Zn}(\mathrm{Zinc})$ & $\mathrm{mg} / \mathrm{kg}$ & 46.27 & 44.62 \\
\hline 6 & OMEGA 3 & $\%$ relative & 17.29 & 6.26 \\
\hline \multirow[t]{6}{*}{7} & Lenolenic Acid & $\%$ relative & $<0.1$ & 0.24 \\
\hline & Eicosatrienic Acid & $\%$ relative & $<0.1$ & 0.93 \\
\hline & Arachidonic Acid & $\%$ relative & $<0.1$ & $<0.1$ \\
\hline & EPA & $\%$ relative & 5.59 & 2.54 \\
\hline & DHA & $\%$ relative & 11.7 & 2.54 \\
\hline & OMEGA 6 & $\%$ relative & $<0.1$ & 8.08 \\
\hline \multirow[t]{3}{*}{8} & Lenoleat Acid & $\%$ relative & $<0.1$ & 7.15 \\
\hline & Eicosadienic Acid & $\%$ relative & $<0.1$ & 0.93 \\
\hline & OMEGA 9 & $\%$ relative & $<0.1$ & 3.63 \\
\hline \multirow[t]{3}{*}{9} & Oleic Acid & $\%$ relative & $<0.1$ & 2.81 \\
\hline & Eicosenic Acid & $\%$ relative & $<0.1$ & 0.82 \\
\hline & Alcaloid Total & $\% \mathrm{~b} / \mathrm{b}$ & 0.04 & 0.45 \\
\hline 10 & Steroid (Sitosterol) & $\mathrm{mg} / \mathrm{kg}$ & $<68$ & $<68$ \\
\hline 11 & Tanin Total (Tannic Acid) & $\% \mathrm{~b} / \mathrm{b}$ & 0.16 & 7.85 \\
\hline 12 & Saponin & $\% \mathrm{~b} / \mathrm{b}$ & 0.86 & 1.36 \\
\hline 13 & Caroten Total & $\% \mathrm{~b} / \mathrm{b}$ & 0.04 & 0.1 \\
\hline
\end{tabular}

\section{Sub-chronic test based on hematology profile}

In order to know the sub-chronic toxicity of Spirulina and Chlorella, the hematology profile test of white rat (Rattus norvegicus) was conducted. The blood profile of the analysis results is shown in tables 4, 5, 6 and 7.

Table 4 shows that total erythrocytes, hemoglobin levels, and hematocrit in the control group tended to increase with the duration of treatment. Although the statistical test analysis is not significant. In contrast, erythrocyte levels, hemoglobin, and total hematocrit from the Spirulina and Chlorella treatment group were decreased with increasing treatment time. Compared to the control group, there was no significant increase in erythrocyte profile during the time of the experiment. It shows that treatment of Spirulina and Chlorella have no toxic impacts based on the erythrocyte profile.

From table 5, it is known that in the control there is a decrease in MCV and $\mathrm{MCH}$ values, and an increase in the MCHC value. Likewise in Spirulina treatment. In Chlorella treatment, the values of $\mathrm{MCV}, \mathrm{MCH}$, and MCHC show no significant level increase.

The second hematological parameter is leukocytes or white blood cells. These leukocytes play a role to keep the body from the antigen. From table 6 , it can be seen that the control number increases on day 30 and then decreases until day 90. In group II that Spirulina treatment, the total leukocyte was relatively constant and slightly decreased on day 90. In Chlorella treatment (group III), the increase of total leukocyte was noted on the day 30, then decreased until day 90. At the first glance, it is noticeable that there are no significant different between control and treatment groups in the leukocyte profile, indicating that Spirulina and Chlorella have no negative impact on the animal model.

The third hematological parameter is platelet profile. Platelets play a role in blood clotting when injuries occur. Table 7 gives information about profile of platelet. In control, there was an increase in total platelet and plateletrit in the first month then decreased in the second and third months. Similarly, it occurs in the treatment of Spirulina with minimum increase and decrease while Chlorella treatment decreased the total platelet and plateletkrit. For PDW values, the control group decreased whereas Chlorella treatment has increased the value of PDW and Spirulina witnessed a fluctuation.

Overall, the main facts that stand out from this subchronic toxicity test was that there are no significant effects on blood profile due to the treatment of Spirulina and Chlorella. It was indicating that both of microalgae have a positive influence and do not have a toxicity effect in the body of experimental animals.

Based on the theory, consumption of Spirulina and Chlorella microalgae can improve body immunity (Tang and Suter, 2011). Previous studies have suggested that Spirulina microalgae has a significant therapeutic effect 
for animals and humans (Watanuki et al., 2006). Spirulina is thought to act as an immunomodulator especially related to the non-specific immune system (Watanuki et al., 2006; Abdel-Tawwab and Ahmad, 2009). While Chlorella contains chlorella growth factor that plays a role in strengthening the immune system and prevent or destroy cancer (Tang and Suter, 2011). Other references suggest that some micronutrients contained in Spirulina and Chlorella such as selenium may help the immune system (Litman et al., 2005).

Table 4. Profile of erythrocyte

\begin{tabular}{ccccc}
\hline Group/Day & & I & II & III \\
\hline & 0 & $6.47 \pm 1.06$ & $7.32 \pm 0.07$ & $7.58 \pm 0.23$ \\
RBC $\left(10^{6} / \mu \mathrm{L}\right)$ & 30 & $6.75 \pm 0.60$ & $6.78 \pm 0.42$ & $7.39 \pm 1.05$ \\
& 60 & $7.72 \pm 0.80$ & $6.64 \pm 0.68$ & $7.79 \pm 0.69$ \\
& 90 & $7.05 \pm 0.07$ & $6.96 \pm 0.22$ & $6.83 \pm 0.31$ \\
\hline \multirow{3}{*}{ Hemoglobin $(\mathrm{g} / \mathrm{dL})$} & 0 & $11.7 \pm 2.4$ & $14.3 \pm 0.2$ & $14.5 \pm 0.3$ \\
& 30 & $11.4 \pm 1.2$ & $13.4 \pm 0.6^{*}$ & $14.6 \pm 1.4^{*}$ \\
& 60 & $13.9 \pm 0.2$ & $12.3 \pm 1.3$ & $14.8 \pm 1.2$ \\
\hline \multirow{3}{*}{ Hematocrit $(\%)$} & 90 & $13.3 \pm 0.6$ & $12.5 \pm 0.9$ & $13.1 \pm 0.9$ \\
& 0 & $38.4 \pm 7.7$ & $41.6 \pm 0.5$ & $43.0 \pm 1.1$ \\
& 30 & $34.9 \pm 2.6$ & $38.0 \pm 2.8$ & $43.0 \pm 4.8$ \\
& 60 & $41.2 \pm 1.6$ & $35.1 \pm 3.7$ & $43.8 \pm 4.1$ \\
\hline
\end{tabular}

*significantly different by Duncan's multiple range test $(p<0.05)$

Table 5. Index of erythrocyte

\begin{tabular}{|c|c|c|c|c|}
\hline & & I & II & III \\
\hline \multirow{4}{*}{ MCV (fL) } & 0 & $59.1 \pm 4.1$ & $56.8 \pm 0.6$ & $56.8 \pm 1.6$ \\
\hline & 30 & $52.1 \pm 8.0$ & $56.1 \pm 2.9$ & $58.4 \pm 1.6$ \\
\hline & 60 & $53.6 \pm 3.7$ & $52.9 \pm 0.3$ & $56.2 \pm 0.2$ \\
\hline & 90 & $56.2 \pm 2.3$ & $53.2 \pm 2.9$ & $56.8 \pm 0.7$ \\
\hline \multirow{4}{*}{$\mathrm{MCH}(\mathrm{pg})$} & 0 & $18.3 \pm 3.6$ & $19.5 \pm 0.2$ & $19.2 \pm 0.5$ \\
\hline & 30 & $17.0 \pm 3.3$ & $19.9 \pm 1.3$ & $19.9 \pm 1.0$ \\
\hline & 60 & $18.1 \pm 1.8$ & $18.5 \pm 0.8$ & $19.0 \pm 0.2$ \\
\hline & 90 & $18.8 \pm 1.0$ & $18.0 \pm 1.6$ & $19.2 \pm 0.6$ \\
\hline \multirow{4}{*}{$\mathrm{MCHC}(\mathrm{g} / \mathrm{dL})$} & 0 & $30.9 \pm 5.1$ & $34.3 \pm 0.2$ & $33.7 \pm 0.1$ \\
\hline & 30 & $32.6 \pm 1.3$ & $35.4 \pm 1.5$ & $34.1 \pm 0.9$ \\
\hline & 60 & $33.8 \pm 1.3$ & $35.0 \pm 1.3$ & $33.8 \pm 0.5$ \\
\hline & 90 & $33.5 \pm 0.6$ & $33.9 \pm 1.2$ & $33.8 \pm 1.0$ \\
\hline
\end{tabular}

*significantly different by Duncan's multiple range test $(p<0.05)$

Table 6. Profile of lymphocyte, WBC and Neutrophyl

\begin{tabular}{ccccc}
\hline Group & & I & II & III \\
\hline & 0 & $5.4 \pm 2.4$ & $7.7 \pm 0.9$ & $7.9 \pm 0.6$ \\
WBC $\left(10^{3} / \mu \mathrm{L}\right)$ & 30 & $10.7 \pm 4.4$ & $7.6 \pm 3.1$ & $9.0 \pm 2.9$ \\
& 60 & $6.3 \pm 1.5$ & $7.7 \pm 2.5$ & $8.4 \pm 2.7$ \\
& 90 & $6.3 \pm 1.0$ & $6.6 \pm 2.3$ & $4.8 \pm 3.8$ \\
\hline \multirow{3}{*}{ Lymphocyte (\%) } & 0 & $70.0 \pm 11.3$ & $71.4 \pm 6.6$ & $70.2 \pm 3.2$ \\
& 30 & $72.8 \pm 13.7$ & $64.1 \pm 8.0$ & $74.0 \pm 4.3$ \\
& 60 & $70.0 \pm 5.5$ & $56.3 \pm 11.7$ & $58.5 \pm 6.0$ \\
\hline \multirow{2}{*}{ Neutrophyl (\%) } & 90 & 0 & $51.0 \pm 21.0$ & 0 \\
& 0 & $16.5 \pm 0.5$ & $28.3 \pm 0.3^{*}$ & $19.5 \pm 0.7^{*}$ \\
& 30 & $23.6 \pm 3.5$ & $37.8 \pm 0.1^{*}$ & $23.9 \pm 6.2$ \\
\hline
\end{tabular}

*significantly different by Duncan's multiple range test $(p<0.05)$

Table 7. Profile of platelet

\begin{tabular}{|c|c|c|c|c|}
\hline & & I & II & III \\
\hline \multirow{4}{*}{$\operatorname{PLT}\left(10^{3} / \mu \mathrm{L}\right)$} & 0 & $523 \pm 540$ & $1003 \pm 478$ & $1259 \pm 235$ \\
\hline & 30 & $1258 \pm 278$ & $1158 \pm 340$ & $1138 \pm 463$ \\
\hline & 60 & $1003 \pm 129$ & $908 \pm 400$ & $976 \pm 288$ \\
\hline & 90 & $1023 \pm 103$ & $972 \pm 530$ & $1022 \pm 197$ \\
\hline \multirow{4}{*}{ Platelecryt (\%) } & 0 & $0.35 \pm 0.36$ & $0.65 \pm 0.28$ & $0.83 \pm 0.15$ \\
\hline & 30 & $0.83 \pm 0.20$ & $0.79 \pm 0.16$ & $0.75 \pm 0.28$ \\
\hline & 60 & $0.62 \pm 0.07$ & $0.58 \pm 0.28$ & $0.67 \pm 0.12$ \\
\hline & 90 & $0.65 \pm 0.06$ & $0.66 \pm 0.35$ & $0.70 \pm 0.09$ \\
\hline \multirow{4}{*}{ PDW (fL) } & 0 & $8.4 \pm 1.2$ & $7.4 \pm 0.8$ & $7.3 \pm 0.1$ \\
\hline & 30 & $7.6 \pm 0.2$ & $8.0 \pm 1.5$ & $7.5 \pm 0.7$ \\
\hline & 60 & $7.0 \pm 0.3$ & $7.1 \pm 0.7$ & $8.2 \pm 1.5$ \\
\hline & 90 & $7.2 \pm 0.2$ & $8.3 \pm 1.8$ & $7.9 \pm 0.6$ \\
\hline
\end{tabular}

*significantly different by Duncan's multiple range test $(p<0.05)$ 


\section{Acknowledgment}

The authors would like to thank the Integrated Research and Testing Laboratory and Biotechnology Laboratory, Faculty of Biology, Universitas Gadjah Mada, Yogyakarta, Indonesia.

\section{References}

Abdel-Tawwab. M., \& Ahmad, M. H. (2009). Live Spirulina (Arthrospira platensis) as a growth and immunity promoter for Nile tilapia, Oreochromis niloticus (L.), challenged with pathogenic Aeromonas hydrophila. Aquaculture Research 40(9), 1037-1046.

Andersen, F. A. (1999). Final report on the safety assessment of azulene. International Journal of Toxicology, 18(3), 27-32.

Bommareddy, A., Rule, B., VanWert, A., Santha, S., \& Dwivedi, C. (2012). $\alpha$-Santalol, a derivative of sandalwood oil, induces apoptosis in human prostate cancer cells by causing caspase-3 activation. Phytomedicine, 19(8-9), 804-811.

Chasapis, C. T., Loutsidou, A. C., Spiliopoulou, C. A., \& Stefanidou, M. E. (2012). Zinc and human health: an update. Archives of Toxicology, 86(4), 521-534.

Dandekar, R., Fegade, B., \& Bhaskar, V. H. (2015). GC-MS analysis of phytoconstituents in alcohol extract of Epiphyllum oxypetalum leaves. Journal of Pharmacognosy and Phytochemistry, 4(1), 149-154.

Cheong, D. S. W., Kasim, A., Sazili, A. Q., Omar, H., \& Teoh, J. Y. (2015). Effect of supplementing Spirulina on live performance, carcass composition and meat quality of Japanese quail. Walailak Journal of Science and Technology, 13(2), 77-84.

Fountain, E. D., Mao, J., Whyte, J. J., Mueller, K. E., Ellersieck, M. R., Will, M. J., Roberts, R. M., MacDonald, R., \& Rosenfeld, C. S (2008). Effects of diets enriched in omega-3 and omega-6 polyunsaturated fatty acids on offspring sex-ratio and maternal behavior in mice. Biology of Reproduction, 78(2), 211-217.

Hoboken, N. J. (2012). Announces the availability of the NIST/EPA/NIH Mass Spectral Library on Wiley Online Library. John Wiley \& Sons, Inc. Retrivied from https://www.wiley.com/Wiley CDA/Section/id-811994.html.

Holman, B. W., \& Malau-Aduli, A. E. (2013). Spirulina as a livestock supplement and animal feed. Journal of Animal Physiology and Animal Nutrition, 97(4), 615-623

Hutadilok-Towatana, N., Reanmongkol, W., \& Panichayupakaranant, P. (2010). Evaluation of the toxicity of Arthrospira (Spirulina) plantesis extract. Journal of Applied Phycology, 22(5), 599605.

Juergen, U. R. (2014). Anti-inflammatory properties of the monoterpene 1.8-cineole: current evidence for co-medication in inflammatory airway diseases. Drug Research, 64(12), 638646.

Lappano, R., Sebastian, A., Cirillo, F., Rigiracciolo, D. C., Galli, G. R., Curcio, R., Malaguamera, R., Belflore, A., Cappello, A. R., \& Maggiolini, M. (2017). The lauric acid-activated signaling prompts apoptosis in cancer cells. Cell Death Discovery, 3, 17063.

Litman, G. W., Cannon, J. P., \& Dishaw, L. J. (2005). Reconstructing immune phylogeny: new perspectives. Nature Reviews Immunology, 5(11), 866-879.

Muñoz-Antoli, C., Cortés, A., Torres, D., Esteban, J., \& Toledo, R. (2015). Haematological changes in the laboratory rat Rattus norvegicus infected with Echinostoma caproni (Trematoda: Echinostomatidae). Journal of Helminthology, 89(5), 636-640.

Nissen, L., Zatta, A., Stefanini, I., Grandi, S., Sgorbati, B., Biavati, B., \& Monti A. (2010). Characterization and antimicrobial activity of essential oils of industrial hemp varieties (Cannabis sativa L.). Fitoterapia, 81(5), 413-419.

Rajeswari, G., Murugan, M., \& Mohan, V. R. (2013). GC-MS analysis of bioactive components of Hugonia mystax L. Bark (Linaceae). Journal of Pharmaceutical and Biomedical Sciences 29(29), 818-824.

Linton, R. E. A., Jerah, S. L., \& Ahmed, I. (2013). The effect of combination of octadecanoic acid, methyl ester and ribavirin against measles virus. International Journal of Scientific \& Technology Research, 2(10), 181-184.

Russo, E. B. (2011). Taming THC: potential cannabis synergy and phytocannabinoid-terpenoid entourage effects. British Journal of Pharmacology, 163(7), 1344-1364

Safayhi, H., \& Sailer, E. R. (1997). Anti-inflammatory actions of pentacyclic triterpenes. Planta Medica, 63(6): 487-493.

Tang, G. \& Suter, P. M. (2011). Vitamin A, nutrition, and health values of algae: Spirulina, Chlorella, and Dunaliella. Journal of Pharmacy and Nutrition Science, 1, 111-118.

Watanuki, H., Kazuki, O., Tassakka, A. C. M. A. R., Toshimitsu, K., \& Sakai, M. (2006). Immunostimulant effects of dietary Spirulina platensis on carp, Cyprinus carpio. Aquaculture, 258(1-4), 157163.

Yang, H., Woo, J., Pae, A. N., Um, M. Y., Cho, N. C., Park, K. D., Yoon, M., Kim, J., Lee, C. J., \& Cho, S. (2016). $\alpha$-Pinene, a major constituent of pine tree oils, enhances non-rapid eye movement sleep in mice through GABAA-benzodiazepine receptors. Molecular Pharmacology, 90(5), 530-539. 